\title{
Three Cases of Refractory Oral/Pharyngeal Ulcers
}

\author{
Naokazu Fujii ${ }^{1)}$, Tetsuya Monden ${ }^{1)}$, Kenichirou Kawaguchi ${ }^{1)}$, Masako Terasaki ${ }^{1)}$ \\ Takeshi Hayashi ${ }^{2}$, Hiroshi Gomibuchi ${ }^{2)}$ and Toshikazu Shimane ${ }^{2)}$
}

We encountered 2 patients who were tentatively diagnosed as having intestinal Behcet's disease during treatment for refractory oral/pharyngeal ulcers, and 1 patient with Crohn's disease. Case 1 was an 83-year-old male. Among the primary symptoms of Behcet's disease, recurrent ulcers of the oral mucosa and vulval ulcer were observed. As an accessory symptom, digestive lesions were detected. A tentative diagnosis of intestinal Behcet's disease was made according to the diagnostic criteria established by the Ministry of Health, Labour and Welfare. Case 2 was an 81-year-old female. Emergency surgery for two perforations in the small intestine was performed, but the patient died. Among primary symptoms of Behcet's disease, recurrent ulcers of the oral mucosa was noted. As an accessory symptom, digestive lesions were detected, leading to a tentative diagnosis of intestinal Behcet's disease. Case 3 was a 22year-old male. Endoscopy of the large intestine revealed digestive lesions and stones, suggesting Crohn's disease. In all patients, the initial symptoms were oral/pharyngeal ulcers, and digestive lesions appeared. The maximum interval from onset until diagnosis was 8 months.

Intestinal Behcet's and Crohn's diseases are difficult to differentiate from oral/pharyngeal mucosal lesions. Endoscopy of the digestive tract may be useful.

Keywords : oral/pharyngeal ulcers, Behcet's disease, Crohn's disease

\section{References}

1）山本祐三，牧本一男：口内炎. 口腔咽頭の臨床（日本口腔 咽頭科学会編)。26-31 頁，医学書院，東京，2009.

2）原㴊保明, 高原 幹：口腔潰瘍. JOHNS 23：1831-1835, 2007.

3）広畑俊成：Behçet 病. 内科学（杉本恒明，小俣政男，水野 美邦編)。1257-1260 頁, 朝倉書店, 東京, 2003.

4) 日比紀文 : Crohn 病. 内科学（杉本恒明, 小俣政男, 水野 美邦編)。993-996 頁，朝倉書店，東京，2003.

5）川上民裕：膠原病の粘膜病変．Derma 125：45-51, 2007.

6）松尾美央子: 難治性口腔咽頭潰瘍の 5 症例. 口腔咽頭科 22:
103-107, 2009

7）小竹 茂：Behçet 病. 膠原病 - リウマチ診療（戸松泰介, 原まさ子, 山中 寿編)。251-273 頁, メジカルビュー社, 東京, 2007 .

8）大原信一郎, 片寄雅彦, 高野 恵, 他 : 反復する口内炎が 診断の契機となった 13 歳発症のクローン病の 1 男児例. 小 児臨 63: 1649-1655, 2010.

9）小林 剛，藤森俊二, 江原彰仁, 他：難治性咽頭潰瘍を伴っ た腸管ベーチェット病の 1 例. Prog Dig Endosc 65: 94-96, 2004.

10）西川 仁，本蔵陽平，日高浩史：診断に苦慮した難治性口 腔咽頭潰瘍の 4 症例.耳鼻免疫アレルギー 29: 7-13, 2011.
1) Department of Otolaryngology, Odawara Municipal Hospital

2) Department of Otorhinolaryngology, Showa University Fujigaoka Hospital
Corresponding Author Address : Naokazu Fujii kuro0975@yahoo.co.jp 

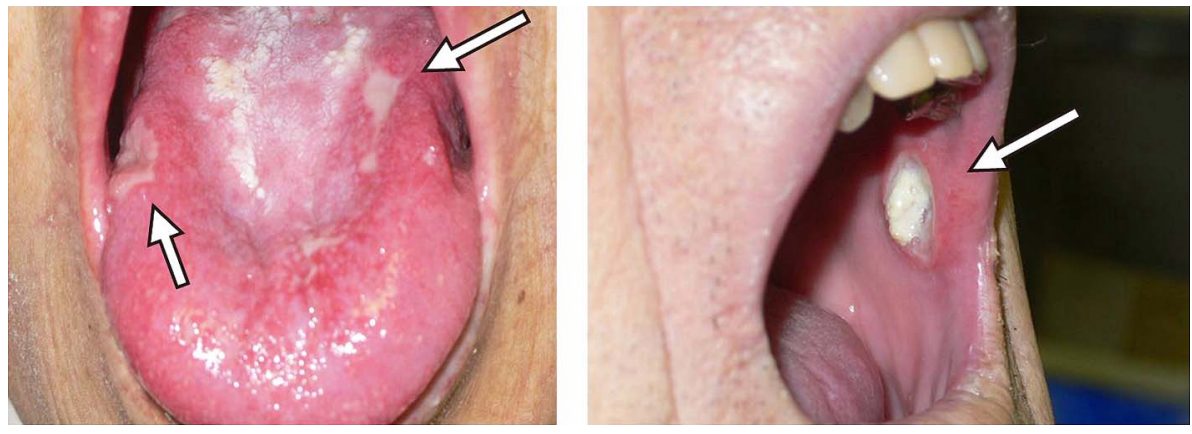

Oral cavity of Case 1 showing multiple ulcers
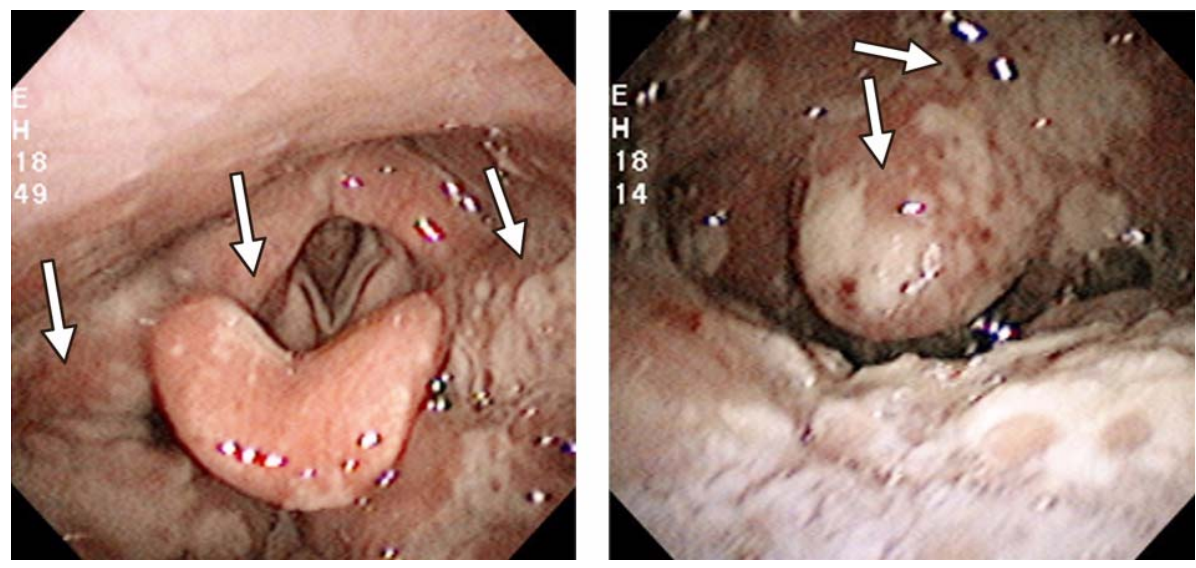

Multiple ulcers and aphthae demonstrating a tendency to coalesce in Case 2

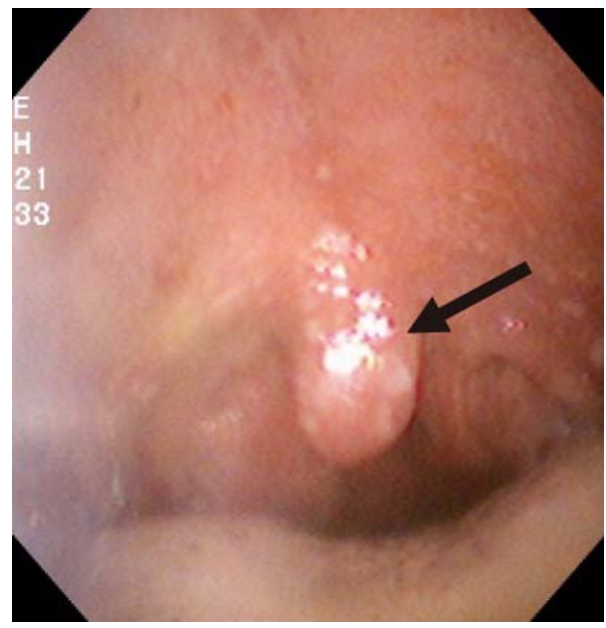

Multiple coalescing aphthae around the uvula in Case 3 